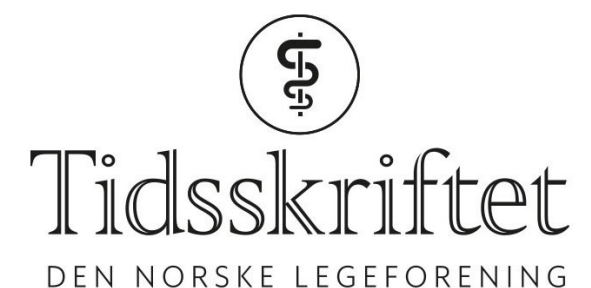

\title{
Hvorfor velger mannlige og kvinnelige leger ulike spesialiteter?
}

LEGELIVET

\section{CECILIE BIRKELI}

E-post: cecilie.normann@legeforeningen.no LEFO - Legeforskningsinstituttet

Motivasjonsfaktorene for valg av spesialiteter er i utgangspunktet ikke så forskjellige blant menn og kvinner, men til slutt velger de likevel ulikt. Er det for lite oppmerksomhet rundt kjønnsforskjeller i medisinsk utdanning?

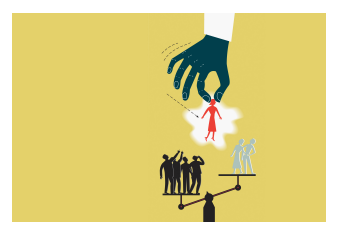

Illustrasjon: Andrew Baker/ NTB

Scanpix

I januar 2019 var $62 \%$ av LIS-legene kvinner (1). Fordelingen i de ulike spesialitetene viser at det fortsatt er menn som dominerer i de såkalte prestisjetunge spesialitetene, for eksempel i kirurgiske spesialiteter med unntak av gynekologi (2) og i ledende stillinger. I thoraxkirurgi er det for eksempel bare fire yrkesaktive kvinnelige spesialister av 66 til sammen (3). Kvinneandelen er også lav innen nevrokirurgi og ortopedisk kirurgi.

En svensk ph.d.-studie viste at klassiske forskjeller mellom menn og kvinner kom til syne mot slutten av studiene, når de unge legene kommer ut i praksis (4). I begynnelsen av studiet var forventningene til utdanningen, karrieren og arbeidslivet ganske like uavhengig av kjønn. Medisinstudentene hadde høye ambisjoner om å kunne kombinere en meningsfull jobb med familie og fritid, og vurderte dette høyere enn lønn og karrieremuligheter. Disse preferansene endret seg underveis i studiet, basert på erfaringene legene gjorde seg da de var i klinisk praksis.

Leger av begge kjønn lot seg avskrekke av klinikker og avdelinger som var preget av et tydelig hierarki, der overtidsarbeid og uforbeholden lojalitet ble oppmuntret. Samtidig fant man at menn og kvinner gjorde seg ulike erfaringer i klinisk praksis, noe som igjen skapte ulike forutsetninger for videre karrierevalg. Begge grupper uttrykte like stort behov for supervisjon underveis i utdanningsløpet, men kvinner opplevde oftere at de fikk mindre tilgang til klinisk praksis enn menn. I flere tilfeller ble de også ekskludert fra supervisjonen.

En betydelig andel av kvinnene beskrev at de hadde mistet interessen for en spesialitet på grunn av et arbeidsklima preget av dårlig arbeidsmiljø og machokultur. De strevde med å 
utvikle yrkesidentitet i større grad enn mennene fordi deres selvforståelse ikke stemte overens med egne profesjonelle idealer og den machokulturen de erfarte. Valg av spesialitet ble dermed en mer kompleks affære hos kvinner. Menn valgte i større grad ut fra ren faginteresse. Mennene som vurderte å bytte spesialitet, begrunnet det med at kunnskapsområdet og arbeidsoppgavene virket kjedelige. De syntes dermed å være friere i sine valg.

Denne studien peker på betydningen av kjønnsforskjeller i valg av spesialitet. Temaet bør vies mer oppmerksomhet, både i legestudiet og ved vikariater eller tidlig i karrieren.

\section{LITTERATUR:}

1. Den Norske Legeforening. Yrkesaktive leger < 70 år i Norge fordelt på stilling per 19.3.2018. https://legeforeningen.no/Emner/Andre-emner/Legestatistikk/Yrkesaktive-leger-i-Norge/Stillingsgrup per/yrkesaktive-leger-70-ar-i-norge-fordelt-pa-stilling-2018-1/(30.1.2018).

2. Album D, Westin S. Do diseases have a prestige hierarchy? A survey among physicians and medical students. Soc Sci Med 2008; 66: 182-8. [PubMed][CrossRef]

3. Den Norske Legeforening. Kjønnsfordeling i hver enkelt spesialitet.

https://legeforeningen.no/Emner/Andre-emner/Legestatistikk/Spesialister/Kjonnsfordeling-i-hver-enk elt-spesialitet/(30.1.2018).

4. Diderichsen S. It's just a job. A new generation of physicians dealing with carees and work ideals. Doktoravhandling. Umeå: Umeå Universitet, 2017: 66.

Publisert: 19. februar 2019. Tidsskr Nor Legeforen. DOI: 10.4045/tidsskr.19.0037

(C) Tidsskrift for Den norske legeforening 2020. Lastet ned fra tidsskriftet.no 